\title{
Investigating Communication Strategies In L2 Learners' Discourse: A Study In Primary Education
}

\author{
Isaak Papadopoulos \\ Aristotle University of Thessaloniki \\ Dimitra Tzamali \\ University of Western Macedonia
}

\begin{abstract}
In cases of language learners' inability to use a word/phrase in the target language, they opt for communication strategies by imitating sounds, inventing new words or using their hands to communicate. Although communication strategies are used very often by students, teachers are not fully aware of their importance during the teaching process and thus they do not train their students to use them. The aim of this study is to evaluate the use of communication strategies by learners of Greek as a second language during the lessons so that it can become obvious to teachers who abandon the message convey or switch to the first language to avoid miscommunication. The researchers used three methodological tools: (1) audio-recordings of naturally occurring classroom interactions and (2) observation notes taken in 25 class sessions. For the interaction transcripts, the researchers used the taxonomy of communication strategies of Faerch and Kasper's (1983) while the researcher's journal was used for the observations. The analysis of the results indicated that the most frequently used strategy used by the students was the language switch while the role of the teacher and the activities implemented each time were crucial as for the communication strategies used by the students.
\end{abstract}

Key words: Communication strategies, bilingual learners, students' interaction, teacher flexibility

\section{INTRODUCTION}

Studies carried out internationally have proved that the strategic competence that speakers develop in their first language could be freely transferable to their second language use (Bongaerts \& Poulisse, 1989; Kellerman, Ammerlaan, Bongaerts, \& Poulisse, 1990). Indeed people have a broad repertoire of communication strategies used in L1 but the use of communication strategies in a second language has been still under discussion. Boxer and Cohen (2004) defined CSs, as "a systematic attempt by the speakers or the learners to deliver or give the exact meaning that is not proportionate with the rules of the target language. O'Malley and Chamot (1990, p. 43) claim that "communication strategies are an adaptation to the failure to realize a language production goal" and Wenden (1987) states that communication strategies are often utilized by learners who emphasize the importance of using the language. Besides, communication strategies (CS) are particularly important "in negotiating meaning where either linguistic structures or sociolinguistic rules are not shared between a second language learner and a speaker of the target language" (O'Malley, \& Chamot, 1990, p.43).

Communication strategies are used by language learners to deal with communication problems and difficulties in conveying their message in the target language. Moreover, communication strategies allow learners to continue in the conversation, which provides them with 
opportunities to receive more input and produce new utterances. According to Dornyei and Scott (1997), these strategies achieve what may be called mutual understanding. As a result, the communication strategies use is beneficial for language learners and can be regarded as a subset of learning strategies that have to do with language skills and subskills and their application in real communication contexts.

Researchers underline that there are many factors that affect the use of communication strategies among the second language learners. For instance, language proficiency of learners (Chen 1990, Tuan 2001), the frequency of speaking the target language (Clement 1986) are some of the most important factors that contribute to the frequent or infrequent use of communication strategies of L2 learners. So, it is obvious that a recording of their use in the a second language and the teachers' tendencies towards them may offer valuable information to second language teachers and students in Greece where bilingual education has started to be received much of the state's attention.

\section{THE STUDY}

Taken into consideration the fact that many teacher education or teaching training programs do not cover the area of communication strategies use so that the second language teachers could help their students, this study aims at investigating the use of communication strategies used by students learning Greek as a second language in Greece. More specifically, this study sets out to investigate the most frequently used communication strategies during the teaching hours so that they can be taken advantage of by the $\mathrm{L} 2$ teachers.

The research questions of this particular study are:

- Which are the most frequent communication strategies used by L2 students?

- Which is the teachers' role when communication strategies are employed by students?

\section{THE SAMPLE}

The participants of this study were students learning Greek as a Second language and teachers of Greek as a second language in central Greece (Larissa). The sample of this place was chosen thanks to the fact that there are many Albanian immigrants in that place who are employed in the agricultural field. Specifically, the sample of this study was 50 Albanian speaking students of primary school at age 11 who are taught the Greek as a second language as an extracurricular activity organized by the Association of Culture in a village of the city (Omorfochori). As for the teaching staff, two teachers were responsible for these Greek language lessons and they were graduates of the University of Western Macedonia with longitudinal training in Bilingualism and Education and speakers of Albanian language as well.

\section{EVALUATION TOOLS}

The data was recorded by the researchers using two methodological tools: (1) audiorecordings of naturally occurring classroom interactions and (2) observation notes taken in 25 class sessions. For the interaction transcripts, the researchers used the taxonomy of communication strategies of Faerch and Kasper's (1983) while the researcher's journal was used for the observations. It should be noted that the classroom interactions were recorded to identify and quantify the communication strategies students spontaneously used while communicating in the teaching hour. The journals were kept to obtain information from the two teachers about their knowledge of communication strategies and the way they take advantage of them. Observation notes were also taken of the students' and teachers' behaviors while communicating in 25 distinct classes. 
The researcher's journal consisted of questions related to the instruction, students' attitude and participation and general estimation of the instruction. More specifically, the questions were:

a) Questions about instruction

1. What objectives did the teacher set? To what extend did he achieve them?

2. What teaching material did he use? How effective were the teaching aids?

3. What forms of communication among students and the teacher were used?

b) Questions about students' attitude and participation

1. Which was the students' attitude at the beginning, middle and at the end of each activity? How did the teacher react?

c) Questions about the general estimation of the instruction.

1. What went well or not?

\section{Researcher's Journal}

\section{RESULTS}

The qualitative analysis of the journal entries led to the creation of four typologies: a) teaching process, b) teacher's role, c) student's attitudes and d Joverall evaluation of the teaching session encompassing a number of categories and subcategories (see Table 1) that can provide information about the communication among students and between the students and the teachers underlining the use of communication strategies and the teacher's role.

Table 1. Journal Records

\begin{tabular}{|c|c|c|}
\hline Typologies & Categories & Subcategories \\
\hline \multirow{3}{*}{ Teaching Process } & $\begin{array}{c}\text { Techniques } \\
\text { And activities }\end{array}$ & $\begin{array}{ll}\circ & \text { Intergroup interaction } \\
\circ & \text { whole class discussion } \\
\circ & \text { creative activities } \\
\circ & \text { brainstorming }\end{array}$ \\
\hline & Teaching Aids & $\begin{aligned} \circ & \text { digital material } \\
& \circ \text { videos } \\
& \circ \text { power point slides } \\
& \circ \text { e-games } \\
\circ & \text { books and posters }\end{aligned}$ \\
\hline & $\begin{array}{c}\text { Forms of } \\
\text { Communication }\end{array}$ & $\begin{array}{ll}\circ & \text { use of mother tongue (L1) } \\
\circ & \text { use of second language (L2) } \\
\circ & \text { nonverbal communication } \\
\circ & \text { code-switch strategy use }\end{array}$ \\
\hline
\end{tabular}




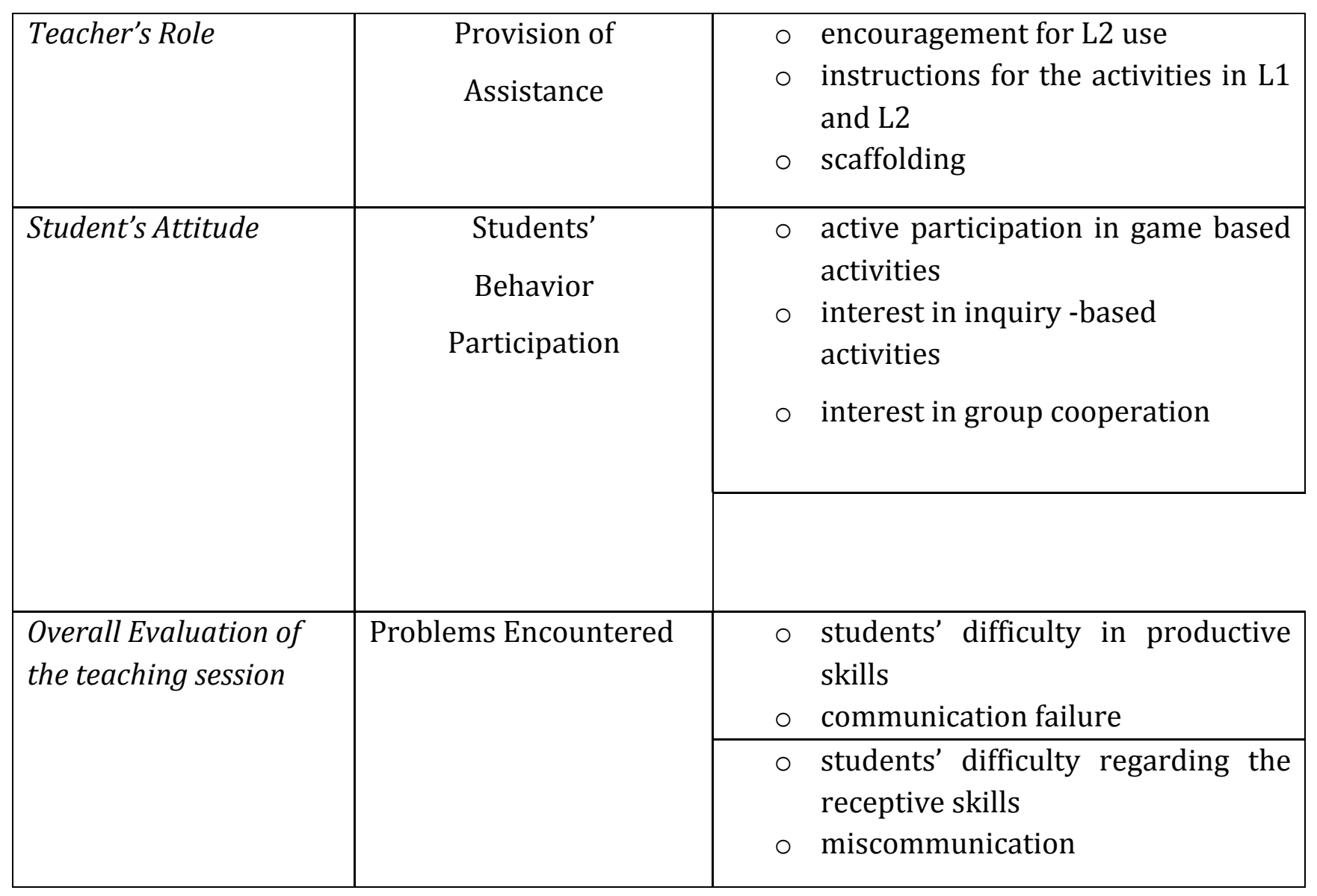

According to the journal recordings, the teachers of this specific research seemed to have implemented a programme of learning Greek as L2 following the current trends in second language teaching. Although the teachers were not aware of the fact that communication strategies used would be examined, their actions and reactions throughout the programme seemed to have encouraged the students' use of CS while they helped them variously in problems encountered regarding the communication and the language skills development. The teachers' tendency towards assistance provision led students to flexible use of CS while the continuous detailed instructions engage students in communication situations where CS were obvious and necessary so that they could convey their message appropriately.

\section{CLASSROOM RECORDINGS}

As it was mentioned above, the framework by Faerch and Kasper (1983) was used for the audio recorded classroom sessions and they were transcribed so that the researcher could be aware of the communication strategies that were used by the students. A frequency form was designed to classify the communication strategies that occurred during the class sessions. 
Table 2. Faerch and Kasper (1983) Communication Strategies Framework

\begin{tabular}{|l|l|l|}
\hline Code & \multicolumn{1}{|c|}{ Strategy } & \multicolumn{1}{|c|}{ Description } \\
\hline C1 & Topic avoidance & Avoid discussions about the concept \\
\hline C2 & Message Abandonment & stop in mid-utterance \\
\hline C3 & Meaning replacement & use altemative expressions \\
\hline C4 & Generalization & use a generalized IL item \\
\hline C5 & Paraphrase & focus on characteristic properties of the intended referent \\
\hline C6 & Word coinage & create a new IL word \\
\hline C7 & Restructuring & restructure one's utterance \\
\hline C8 & Approximation & use an incorrect item that shares some semantic features \\
\hline C9 & Literal translation & translate literally \\
\hline C10 & Language switch & insert words from native language \\
\hline C11 & Foreignizing & apply IL modification to the L1 item \\
\hline C12 & Mime & replace a word with nonverbal cues (kinesthetically) \\
\hline C13 & $\begin{array}{l}\text { Code-based confirmation } \\
\text { check }\end{array}$ & repeat the previous utterance for confirmation \\
\hline C14 & Positive confirmation check & ask for confirmation \\
\hline C15 & Clarification request & attempt to check comprehension \\
\hline C16 & Comprehension check & attempt to check comprehension \\
\hline C17 & Other reformulation & model the speaker's previous utterance \\
\hline C18 & Repetition & repeat utterance \\
\hline
\end{tabular}

"Intra-individual communication strategies. This view locates CSs in models of speech production or cognitive organization and processing models.

"Inter-individual communication strategies. This perspective allows for an inclusion of various repair mechanisms (the negotiation of meaning between interlocutors).

Table 3. The sample of the study

\begin{tabular}{ccc}
\hline & $\underline{\text { Number }}$ & Percentage \\
\hline$\underline{\text { Males }}$ & $\underline{26}$ & $\underline{52 \%}$ \\
$\underline{\text { Females }}$ & $\underline{24}$ & $\underline{48 \%}$ \\
\hline
\end{tabular}

The following table shows the use of communication strategies by the bilingual students who participated in this particular study as they were transcribed by the researchers who observed 25 class sessions. As it becomes obvious, the most frequently use communication strategy is the "Language switch" (90\%) while students used at a high rate the "Repetition" (84\%), "Asking information" (76\%) and "comprehension check" and "paraphrasing" (74\%) strategies as well. Moreover, it is very important to state that strategies of "Translation" and "Meaning replacement" (60\%) were used by the students too while "Generalization" (58\%) and "Approximation" and "Restructuring" (56\%) were also among the most commonly used strategies of students. 
Table 4. Communication strategies use

Strategy
Frequency of Use

\section{Frequency of Use}

(Number of students that used the (Percentage of students that used the

CS)

\begin{tabular}{|ccc|}
\hline Language switch & 45 & $90 \%$ \\
\hline Repetition & 42 & $84 \%$ \\
\hline Asking confirmation & 38 & $76 \%$ \\
\hline $\begin{array}{c}\text { Comprehension } \\
\text { check }\end{array}$ & 37 & $74 \%$ \\
\hline Paraphrasing & 37 & $74 \%$ \\
\hline Clarification request & 35 & $70 \%$ \\
\hline Translation & 30 & $60 \%$ \\
\hline $\begin{array}{c}\text { Meaning } \\
\text { replacement }\end{array}$ & 30 & $60 \%$ \\
\hline Generalization & 29 & $58 \%$ \\
\hline Approximation & 28 & $56 \%$ \\
\hline Restructuring & 28 & $56 \%$ \\
\hline
\end{tabular}

Following the quality analysis of the class sessions recordings, here are some extracts that exhibit the use of some communication strategies.

( $\mathrm{T}=$ teacher $\& \mathrm{~S}=$ Student $)$

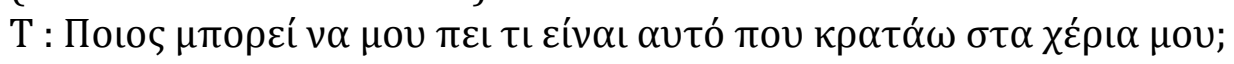

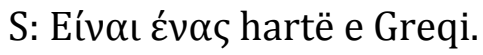

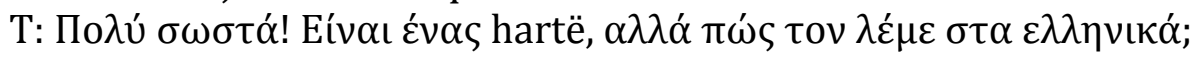

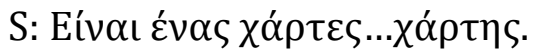

(English translation)

T: Who can tell me what this that I hold is?

S: This is a hartë of Greqi

T: Very nice! This is a hartë, but how can we call it in Greek?

$\mathrm{S}$ : This is a mep...a map!

The above mentioned passage is related to the language switch of the student in the case of the word "map" that he was not able to say/remember.

Another very representative example of communication strategies use is the restructuring and generalization.

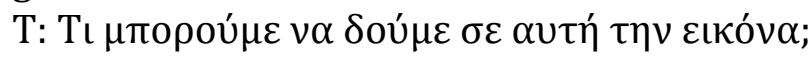




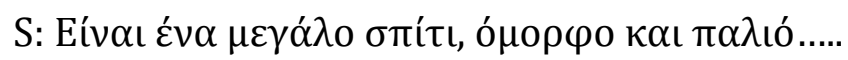

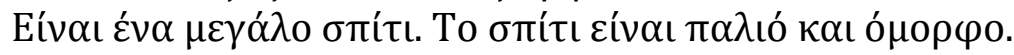

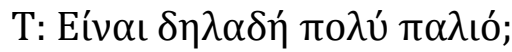

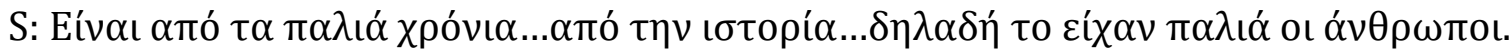

(English translation)

$\mathrm{T}$ : What can we see in this picture?

S: It's a big house, beautiful and old....

It's a big house. The house is old and beautiful.

T: Is it really very old?

S: Yes, from the past...from the history..that is to say, people had it in the past.

Based on the journals and audio recording, it became obvious that the CS were mostly employed by students when they needed to know how to say a word, when they had doubts about the lesson and when the teacher asked them questions. Thanks to the game based activities, the students used communication strategies when they did not know how to say a word. They usually asked the teacher in Albanian and very rarely in the target language (Greek) while the teachers gave their explanation in Greek and then in Albanian when the students could not fully understand the meaning. In fact, the activities offered the opportunity to students to express themselves free in the language code they prefer and they encourage the use of CS when they faced a communication difficulty. Moreover, the students used the above mentioned CS when the teachers asked questions related to either everyday matters or lesson matters but it was very often for the students to use the L1 to avoid miscommunication of communication failure and the transcriptions showed that the teachers' reactions did not prevent students from employing communication strategies

\section{CONCLUSIONS}

The aim of this particular study was to examine the communication strategies that are used by bilingual students in Greece. For the data collection, the researcher observed and recorded 25 class sessions while he kept journals throughout the teaching hours. The recordings were transcribed and coded using the Faerch and Kasper's (1983) taxonomy of communication strategies. Following the quality and quantity process of results revealing, the study indicated that the most commonly used communication strategies among the bilingual students of Greek as L2 were language switch, repetition, asking confirmation and comprehension check while there are several strategies that were not used possibly because of the activities that students were engaged in.

While the class observation indicated the above mentioned use of strategies, the journals recordings exhibited valuable information about what is happening in the classroom throughout the teaching hour. It became obvious that students used very often their mother tongue in every difficulty they had while the teachers' role proved to be encouraging and supportive for the sake of students' learning. More specifically, the teachers implemented a pleasure learning programme that was characterized with game based activities and digital material that proved to encourage students to use communication strategies when they have difficulties in conveying their message in L2. Students participated in these activities seemed to use more often communication strategies because they seemed to be more flexible and they participate in game based activities.

Moreover, the group interaction and the class cooperation activities and techniques that the teachers used encourage students to use CS when problematic message transfer occurred 
among them while they tried to use the L2 with the help of their classmates and their teachers in a free-stressed environment. Students used a variety of communication strategies in every activity they were engaged in and the teachers' role was more than helpful and welcoming. As the journal recordings show, among the forms of communication L1, L2 and non verbal communication and code switching were always obvious while the teachers' role with continuous provision of assistance were combined and increased the use of CS.

According to Dörnyei (1995) the communication strategies should be taught at schools and with reference to this study, teachers and students were not aware of the communication strategies but teachers encouraged the use of them through the activities that they implemented unconsciously. As the literature suggests, the communication strategies are very important in the SL classroom and this study may come in very handy for everyone involved in the field of education. A training on communication strategies to all SL educators may lead to an expansion of the CS use outside the classroom in real life situation so that all people can sole communication problems and message conveys.

\section{References}

Bongaerts, T., and Poulisse, N. (1989). Communication strategies in L1 and L2: Same or different? Applied Linguistics, 10(3), 253-268.

Boxer and Cohen (2004), Chapter 12. C. Roever. Difficulty and practiciality in tests of interlanguage pragmatics, pp. 283-301

Chen, S.Q. "A Study of Communication Strategies in Interlanguage Production By Chinese EFL Learners." Language Learning, vol. 40 (2), pp. 155-187,1990 Retrieved September 19, 2011 from http://onlinelibrary.wiley.com/doi/10.1111/j.1467

Clement, R. (1986). Second language proficiency and acculturation: An investigation of the effects of language status and individual characteristics. Journal of Language \& Social Psychology, 5, 271-290.

Dörnyei, Z. (1995). On the teachability of communication strategies. TESOL Quarterly, 29, 55-85.

Færch, C., \& Kasper, G. (1983). On identifying communication strategies in interlanguage production. In C. Færch \& G. Kasper (Eds.), Strategies in interlanguage communication (pp. 210-238). London: Longman

Kellerman, E., Ammerlaan, T., Bongaerts, T., \& Poulisse, N. (1990). System and hierarchy in L2 compensatory strategies. In R. C. Scarcella, E. S. Andersen, \& S. D. Krashen (Eds.), Developing communicative competence in a second language, (pp. 163-178). New York: Newbury House

Kellerman, E., Ammerlaan, T., Bongaerts, T., and Poulisse, N. (1990). System and hierarchy in L2 compensatory strategies. In R.C. Scarcella, E.S. Andersen, and S.D. Krashen (Eds.), Developing communicative competence in a second language. (pp.163-178). Boston, MA: Heinle \& Heinle Publishers.

O'Malley, J.M. \& Chamot, A.U. (1990). Learning Strategies in Second Language Acquisition. Cambridge: Cambridge University Press.

Tuan, H.J. “Is Extroversion-Intriversion Tendency A Variable in The Choice of Strategies in Communication?" in: Proceedings of the Eighteenth Conference on English Teaching and Learning in the Republic of China Taipei:

Crane. Pp.306-324, 2001 


\section{SEMI-BIO}

Isaak Papadopoulos has been a SL/FL teacher \& Oral examiner for the Department of Education of Ireland while he is currently working as a Teachers' Trainer. He holds a bachelor in Primary School Education (University of Western Macedonia, Greece), a master degree in Dyslexia and Foreign Language learning (University Roma 3, Italy) and he is a PhD Candidate at the Aristotle University of Thessaloniki in the field of Applied Linguistics. His research and publication interests include teaching of the second/foreign language, the development of CLIL program, language teachers' development and the evaluation of the language skills. He has participated and attended many conferences while he is coordinating several projects about innovative practices in language learning and the training of oral examiners. He is reviewer and has published many papers in international journals and he has published his first course book for elementary EFL learners and it is used in Greece and Cyprus in private centers of CLIL education. 